\title{
Setting priorities for EU healthcare workforce IT skills competence improvement
}

Sisi $\mathrm{Li}^{1}$, Panagiotis D Bamidis ${ }^{2 *}$, Stathis Th. Konstantinidis ${ }^{3}$, Vicente Traver ${ }^{4}$, Josip $\mathrm{Car}^{5}$, Nabil Zary ${ }^{1}$

${ }^{1}$ Karolinska Institutet, Stockholm, Sweden;

${ }^{2}$ Aristotle University of Thessaloniki, Thessaloniki, Greece;

${ }^{3}$ The University of Nottingham, Nottingham, United Kingdom;

${ }^{4}$ Universitat Politècnica de València, Valencia, Spain

${ }^{5}$ Imperial College, London, United Kingdom

"This paper is a preprint of a paper accepted by Health Informatics Journal (ISSN: 14604582). When the final version is published, the copy of record will be available at Sage Publishing : http://journals.sagepub.com/home/jhi" 


\section{Setting priorities for EU healthcare workforce IT skills competence improvement}

Sisi $\mathrm{Li}^{1}$, Panagiotis D Bamidis ${ }^{2 *}$, Stathis Th. Konstantinidis ${ }^{3}$, Vicente Traver ${ }^{4}$, Josip $\mathrm{Car}^{5}$, Nabil Zary ${ }^{1}$

${ }^{1}$ Karolinska Institutet, Stockholm, Sweden;

${ }^{2}$ Aristotle University of Thessaloniki, Thessaloniki, Greece;

${ }^{3}$ The University of Nottingham, Nottingham, United Kingdom;

${ }^{4}$ Universitat Politècnica de València, Valencia, Spain

${ }^{5}$ Imperial College, London, United Kingdom

\section{* Corresponding author:}

Panagiotis Bamidis,

Medical School, Aristotle University of Thessaloniki, 54124 Thessaloniki, Greece

Email: bamidis@med.auth.gr

Phone: +302310999310 


\begin{abstract}
A major challenge for healthcare quality improvement is the lack of IT skills and knowledge of healthcare workforce as well as their ambivalent attitudes towards IT. This paper identifies and prioritises actions needed to improve the IT skills of healthcare workforce across the EU. 46 experts, representing different fields of expertise in healthcare and geolocations systematically list and scored actions that would improve IT skills among healthcare workforce. The Child Health and Nutrition Research Initiative methodology was used for research priority-setting. The participants evaluated the actions using the following criteria: feasibility, effectiveness, deliverability, and maximum impact on IT skills improvement. The leading priority actions were related to appropriate training, integrating eHealth in curricula, involving healthcare workforce in the eHealth solution development, improving awareness of eHealth and learning arrangement. As the different professionals' needs are prioritised, healthcare workforce should be actively and continuously included in the development of eHealth solutions.
\end{abstract}

Keywords: healthcare workforce, priority setting, IT skills competence, CHNRI 


\section{Introduction}

Healthcare systems throughout the world are endeavoring to rise to the challenges that result from ageing population, prevalence of chronic conditions, rising life expectations and multi-morbidity [1]-[3]. The traditional healthcare delivery is unsustainable and is increasingly recognized that integrated care can significantly improve the quality and continuity of services [4]. With the focus on creating more efficient and cost-effective care, eHealth is seen as one of the key solutions. An EU report indicated that eHealth has the potential to be the third pillar in the health market, along with pharmaceuticals and medical devices [5]. The 2010 EU Citizenship Report underlined the role of eHealth in facilitating cross border healthcare [6]. The focus of is to advance and create new models for delivering better quality, more efficient healthcare services and not to replace traditional ways of care delivery, such as face-to-face consultations.

According to the EU project "Chain of Trust", which analyzed the experience of 6704 patients' and health professionals' who used eHealth two most prominent topics were the confidence in health IT and health professionals' skills [7]. Traditional curricula commonly do not equip healthcare workforce even with the basic health IT skills. Identifying approaches for achieving a highly proficient in eHealth healthcare workforce including those working in public health, and allied professionals is a key to healthcare transformation.

The need to improve the eHealth/IT competences of healthcare workforce has been frequently emphasized by policymakers at an international level. One of the projects aiming to identify healthcare workforce IT skills needs is the CAMEI project [8]-[10]. It is a collaboration between the US and Europe, which was initiated by the Memorandum of Understanding on Cooperation Surrounding Health-Related Communications and Technologies [11]. Other studies focus on some specific areas or workforce groups [12]-[15]. In this study, we use the WHO definition of healthcare workforce as "all people engaged in action whose primary intent is to enhance 
health"[16]. The eHealth/health IT skills are defined as "any competence and knowledge deficiencies among all staff in healthcare delivery, management, administration and support to ensure universal application of ICT solutions in health services."[17]

To our knowledge, this is the first study that used a systematic approach to setting priorities for the IT skills competence development among healthcare workforce. A bottom-up approach, with collaboration between experts from diverse backgrounds in healthcare is the way to ensure the health IT skill issues faced by healthcare workforce be addressed appropriately. The objective of this study was to identify and prioritise the actions needed to develop the IT skills competence among healthcare workforce

\section{Methods}

The study was approved by the Bioethics Committee of the Medical School of the Aristotle University of Thessaloniki, Greece (Approval No.94/26-06-2014). Relevant information about the study was presented to the participants when asking for their consent of participation. The information covered the standard domains of identifying the researchers, the study purpose and procedures, confidentiality, and how to contact the researchers with any questions or to obtain study results. The way to use the participants' response was also informed as well as their impact on the results. Their response to the questionnaire indicated their understanding and willingness to participate in the study. Due to the various geographical locations of participants, the information was sent via emails.

Our research is about collecting basic and non-sensitive information. No harm is made to the participants. The collected data can only be used for research purposes and is stored accordingly to social science research guidelines. All the participants were not given any information about the data obtained from one another. All the data were analyzed anonymously. No comparison was made from one participant's opinion to 
another. Taking into account the collected data, it was presented as it was without altering it to satisfy certain predictions. The participants in this study didn't receive and weren't promised any forms of compensation in return.

The Child Health and Nutrition Research Initiative (CHNRI) methodology for priorities setting was used to assist prioritizing actions in this study [18]. The process uses a systematic and transparent approach to assemble and analyze a wide spectrum of collective actions from an array of healthcare experts. Prioritization criteria relevant to the topic were used to score and rank the actions. The CHNRI methodology has been used previously to identify research gaps and resource priorities in areas such as birth asphyxia and mental health and it is increasingly being used by policy makers, large donors, and international organizations [18]-[20]. Fig 1 illustrates the four stages of CHNRI methodology:

\section{Fig 1. CHNRI methodology process}

\section{Stage 1: Define the context and criteria}

Defining the context is a critical part of the CHNRI process as priority scores for many actions may strongly depend on the context in which the process takes place. The context for this study was specified as follows:

- Scale of the study: EU

- Problem: deficiency of IT skills competence

- Target population: healthcare workforce

Based on CHNRI's conceptual framework [18], four scoring criteria were identified: (i) feasibility; (ii)effectiveness; (iii)deliverability, affordability, and sustainability; (iv) maximum potential impact on competence improvement.

\section{Stage 2: Experts input - listing and scoring actions}

46 leading experts, representing different expertise and geographical locations, were 
invited to participate on the basis of their record in eHealth or their membership in an international health organization, mainly include:

- American Health Information Management Association (AHIMA)

- Computer-Based Medical Systems Committee (CBMS)

- $\quad$ Standing Committee of European Doctors (CPME)

- European Association of Hospital Pharmacists (EAHP)

- European Federation for Medical Informatics (EFMI)

- $\quad$ European Federation of Nurses Association (EFN)

- Healthcare Information and Management Systems Society (HIMSS)

- International Medical Informatics Association (IMIA)

- Joint Information Systems Committee (JISC)

- Medical Informatics Europe Committee (MIE)

- Health Level Seven International (HL7)

- openEHR initiative stakeholders

29 experts from 14 countries participated in the study listing actions via web survey in March 2015, while 34 experts from 19 countries scored actions via web survey from April to May 2015. There was an overlap of 17 experts who were involved in both processes, showed in Fig 2. In the listing process, experts proposed actions that they thought were important to improve IT skills competence among healthcare workforce. The experts were from 14 countries, including US, UK, Finland, Norway, Iceland, Switzerland, Denmark, German, Spain, Czech Republic, Ireland, Austria, Belgium and Netherlands. Among 29 experts, 10\% were academics or researchers only, about $69 \%$ were academics or researchers and belonged to a non-governmental organization (NGO), and $21 \%$ were from NGO only. The process was open-ended and all the proposed ideas from each of the experts were collected independently. The list of actions was compressed to highlight important gaps, yet still represent the range of possibilities to improve IT skills. Then the final list of actions was reviewed by the authors to ensure that they were framed correctly and comprehensively to allow scoring. 


\section{Fig 2. Experts' recruitment process}

In the scoring process, experts evaluated the final list of actions independently according to the criteria as described in Stage 1. Every expert scored all four criteria, which limiting potential impact of any single expert on overall scores. In this way, the listed actions received four "intermediate scores", ranging from $0 \%$ to $100 \%$. These values represented a direct measure of the collective optimism of the experts. In addition to the 14 countries in the listing process, more experts from Sweden, Greece, Kosovo, Slovenia, and Bulgaria participated in the scoring process. Among 34 experts, $17 \%$ of them were academics or researchers only, about $59 \%$ were academics or researchers and belonged to a non-governmental organization (NGO), and 24\% were from NGOs only.

Apart from EU countries, experts from the US were also invited to participate in the study due to the collaboration between the European Commission and the United States in actively addressing the needs for skilled workforce [11]. This was also necessary to make sure that identifying approaches to develop IT skills competence involved a diverse group of experts (rather than isolate EU experts only).

Fig 3 illustrates the expertise of participants in both listing and scoring processes, mainly included:

- eHealth: EHR, telehealth, clinical decision support, healthcare information system, health knowledge management

- Health informatics: medical informatics, nursing informatics and biomedical informatics

- eLearning and education

- Standardization: SNOMED CT, interoperability

- Clinical expertise: medical doctor, nursing and pharmacy 
A full list of experts with their expertise and affiliations are presented in S1 and S2 Tables.

\section{Stage 3: Address external stakeholder's value}

The CHNRI methodology ensures the involvement of stakeholders in the process regardless of their expertise. The term "stakeholders" refers to all individuals and/or groups who have an interest in the prioritization of health research, therefore will comprise a large and very heterogeneous group (e.g. expected recipients of the research, taxpayers, medical students, health workers, journalists and media, political experts, etc.) [18]. They lack expertise to directly decide research priorities, but they can still weigh the chosen priority-setting criteria based on values assigned by them [21]. In this study, it was decided that the external stakeholder's value will not be addressed and final rankings were based on the priority scores from the perspectives of experts.

\section{Stage 4: Compute priority scores and assign ranks}

Each expert scored each action by answering one question per criterion. According to CHNRI framework [18], the answers to each question are simply: "Yes" (1 point) or "No" (0 points). When the experts were sufficiently informed to answer the question, but can neither agree nor disagree, they were allowed to choose "Undecided" (0.5 points). Furthermore, when the experts didn't feel they have enough knowledge to answer some questions, they chose "Unqualified to answer". Thus, the listed actions got a score for each of the four criteria. The overall scores were calculated as the mean of the scores for the four criteria according to the formula:

$[($ Criterion 1 score $)+($ Criterion 2 score $)+($ Criterion 3 score $)+($ Criterion 4 score $)] / 4$

\section{Results}

The full list of 23 actions and scores from each individual expert are presented in S3 Table. The results exposed how actions can be prioritised depending on the criterion of 
feasibility, effectiveness, deliverability and maximum potential impact on competence improvement.

Table 1 shows the ten actions with greatest overall priority score. The action that achieved highest score was about integration of health information technology in curricula for healthcare workforce at different levels (85.1). In addition to that, other actions that focus on continuing training among healthcare workforce also obtained high scores. The action about ensuring the trainer competence was ranked second (84.5); training on patient-centered eHealth services was fifth (83.6); training on role-specific IT skills was sixth (80.3) and training on the development of processes and activities supported by IT solutions was tied ninth (75.6).

\section{Table 1. Ten actions with greatest overall priority score}

F:Feasible, E:Effective, D: Deliverable, M:Maximum impact, PS: Overall priority score

\begin{tabular}{|c|c|c|c|c|c|c|}
\hline Rank & Action & $\mathbf{F}$ & $\mathbf{E}$ & $\mathbf{D}$ & $\mathbf{M}$ & PS \\
\hline 1 & $\begin{array}{l}\text { Integrate health IT in curricula at } \\
\text { both undergraduate and } \\
\text { postgraduate level }\end{array}$ & 92.6 & 95.5 & 75.8 & 76.7 & 85.1 \\
\hline 2 & $\begin{array}{l}\text { Ensure the competence for } \\
\text { educators, train the trainer in } \\
\text { eHealth IT skills }\end{array}$ & 88.2 & 92.4 & 79.0 & 78.3 & 84.5 \\
\hline 3 & $\begin{array}{l}\text { Raise awareness of the importance } \\
\text { of eHealth }\end{array}$ & 88.2 & 86.3 & 85.5 & 77.6 & 84.4 \\
\hline 4 & $\begin{array}{l}\text { Inclusion of healthcare } \\
\text { professionals in the development } \\
\text { process of the ICT-solutions (e.g. } \\
\text { usability testing of software) }\end{array}$ & 92.6 & 89.4 & 83.9 & 70.0 & 84.0 \\
\hline 5 & $\begin{array}{l}\text { Training on patient-centered } \\
\text { eHealth/Health IT services for } \\
\text { different professional groups }\end{array}$ & 91.2 & 89.4 & 82.2 & 71.7 & 83.6 \\
\hline 6 & $\begin{array}{l}\text { Training on role specific and } \\
\text { organization-specific IT skills for } \\
\text { different professional groups }\end{array}$ & 83.8 & 84.8 & 79.0 & 73.3 & 80.3 \\
\hline 7 & Exposure to relevant ICT solutions & 88.2 & 81.8 & 77.4 & 73.3 & 80.2 \\
\hline
\end{tabular}


and medical technologies, increase

users' confidence in eHealth

$\begin{array}{lllllll}8 & \text { Improve learning arrangements }- & 81.2 & 87.5 & 65.0 & 76.7 & \mathbf{7 7 . 6}\end{array}$ facilities, methods, equipment

$\begin{array}{lllllll}9 & \text { Training on the development of } & 77.9 & 80.3 & 74.2 & 70.0 & \mathbf{7 5 . 6}\end{array}$ processes and activities supported by IT solutions for different professional groups

$\begin{array}{llllllllll}10 & \text { Increase } & \text { research in } & \text { user } & 85.2 & 81.8 & 69.3 & 63.8 & \mathbf{7 5 . 1}\end{array}$ acceptance of IT for healthcare workforce

Two high-scoring actions were related to improve the workforce involvement: inclusion of healthcare workforce in the development process of eHealth (ranked 4th) and research in user acceptance (10th). High scores were also given to two related actions that identified education on eHealth, specifically for and improving awareness (3rd) and increasing confidence (7th).

Table 2 shows the ten lowest-scoring actions. Concerns about feasibility were expressed for actions related to identification of IT skills competence needed at international level (ranked 16th, feasibility score 74.2), evaluate of skills of existing and new staff, offer qualification procedure (19th, feasibility score 73.5), and Joint funding for training programs (20th, feasibility score 66.7). For the effectiveness criteria, experts identified actions that introduce online training tools and in housing training for different healthcare workforce as less effective (14th, effectiveness score 74.2). Other effective action was related to helping workforce recognize eHealth/health IT as a specialty (17th, effectiveness score 68.1).

Table 2. Ten actions with lowest overall priority score

F:Feasible, E:Effective, D: Deliverable, M:Maximum impact, PS: Overall priority score

\begin{tabular}{clccccc|} 
Rank & Action & F & E & D & M & PS \\
\hline $\mathbf{1 4}$ & Introduce online training tools, & 83.3 & 73.4 & 66.7 & 66.7 & $\mathbf{7 2 . 5}$
\end{tabular}




\begin{tabular}{|c|c|c|c|c|c|c|}
\hline & $\begin{array}{l}\text { e.g. MOOC, as well as in } \\
\text { housing training }\end{array}$ & & & & & \\
\hline 15 & $\begin{array}{l}\text { Analysis the skills needed for } \\
\text { jobs }\end{array}$ & 81.2 & 77.2 & 67.7 & 55.0 & 70.4 \\
\hline 16 & $\begin{array}{l}\text { Identification of IT skills } \\
\text { competence needed at } \\
\text { international level, allow } \\
\text { recognition of competences } \\
\text { beyond frontiers, create of } \\
\text { competence framework }\end{array}$ & 74.2 & 75.0 & 72.4 & 58.3 & 70.0 \\
\hline 17 & $\begin{array}{l}\text { Help to } \quad \text { recognize } \\
\text { eHealth/health IT as a specialty }\end{array}$ & 77.9 & 68.1 & 71.7 & 61.7 & 69.7 \\
\hline 18 & $\begin{array}{l}\text { Guarantee the governance for } \\
\text { education and training }\end{array}$ & 82.3 & 72.7 & 53.2 & 56.7 & 66.2 \\
\hline 19 & $\begin{array}{l}\text { Carry out regular audit / evaluate } \\
\text { of skills of existing and new } \\
\text { staff, offer qualification } \\
\text { procedure }\end{array}$ & 73.5 & 74.2 & 53.2 & 56.7 & 64.4 \\
\hline 20 & $\begin{array}{l}\text { Joint Funding for generic } \\
\text { training programs }\end{array}$ & 66.7 & 68.2 & 55.0 & 61.7 & 62.9 \\
\hline 21 & $\begin{array}{l}\text { Set up coordinating body to } \\
\text { support availability of ICT in } \\
\text { broad community of healthcare } \\
\text { workers }\end{array}$ & 58.8 & 59.1 & 53.3 & 55.0 & 56.6 \\
\hline 22 & Create and use registries & 57.6 & 58.0 & 53.4 & 50.0 & 54.7 \\
\hline 23 & $\begin{array}{l}\text { Improving training on potential } \\
\text { healthcare workforce at high } \\
\text { school level, undergraduate } \\
\text { level }\end{array}$ & 50.0 & 51.6 & 41.4 & 48.3 & 47.8 \\
\hline
\end{tabular}

Several actions reached the bottom line because they had low scores in the likelihood that these actions could be deliverable, affordable, and sustainable taking into account the current resources. These actions included guaranteeing the governance for education and training (18th, deliverability score 53.2), setting up coordinating organizations to support availability of ICT in broad community of healthcare workforce (21st, deliverability score 53.3) and improving training on potential 
healthcare workforce (23rd, deliverability score 41.4). Two actions that proposed to analyze the IT skills needed for jobs and create registries (15th and 22nd, maximum impact score 55.0 and 50.0) received low priority scores because they were perceived have less impact on the improvement of IT skills competence.

To summarize, the action that proposed to integrate health IT in curricula was acknowledged as most feasible (92.6) and effective (95.5). Raising awareness of the importance of eHealth was considered to be most deliverable (85.5) while ensuring the competence for educators could impact on the IT skill improvement most (78.3).

\section{Discussion}

\section{Main findings}

Prioritization mechanisms are necessary to facilitate the current demand for skilled healthcare workforce, particularly competence to support national eHealth work agendas [14], [15]. The overall message of this prioritization study suggests that actions to improve IT skills competence among healthcare workforce in the EU should concentrate on improving workforce training, the inclusion of healthcare workforce in the development of eHealth solutions, raising awareness of eHealth as well as improving learning arrangements. The results are generally in line with the recommendations from a recent eHealth Stakeholder Group report [22] that focused on eSkills and health workforce.

Of the top ten actions, five were related to training among healthcare workforce, which reflects the significance of continuous training in IT skills development since the gap between current curriculum and eHealth [23], [24]. The importance of training for healthcare workforce in the use of new technologies was also acknowledged in several studies as well as a Green Paper on the EU health workforce [25]-[27]. Moreover, the results showed the great need of involving healthcare workforce in decisions on introducing eHealth, as well as in designing, testing and deploying eHealth. Similar 
results were also demonstrated in another study, user involvement is perceived as crucial to ensuring acceptance in the long term [7]. Furthermore, improving learning arrangements was considered as an essential approach to improve the workforce IT skills. It has been identified by Rachel [28] that being limited or with not enough access to technology was one of the top ten challenges faced by healthcare workforce.

The 2012 Action Plan for the EU Health Workforce from the European Commission [29] outlined three priority areas of actions to promote a sustainable healthcare workforce: forecasting workforce needs and improving workforce planning methodologies, anticipating future skills needs in the health professions, and share good practice on effective recruitment and retention of health professionals. However, the two actions related to identify the IT skills needed did not feature as highly despite being crucial for future workforce plan. These lower prioritizations were due to the concerns on the maximum impact on IT skill improvement.

Two exception actions addressed training issues, "introduce online training tools" and "training on potential workforce", respectively, were ranked low priorities. Although a recent systematic review of the effectiveness of online eLearning suggested that eLearning possibly superior to traditional learning [30], experts probably feel the actions were not deliverable, affordable, and sustainable.

Scores for feasibility and effectiveness of the 23 actions were relatively higher than deliverability and maximum impact. For instance, while the action "Guarantee the governance for education and training" scored $82.3 \%$ on feasibility, it scored poorly on deliverability (53.2\%). This illustrates the fundamental characteristics of health system delivery across the EU. Similar to the EU, the health care delivery system in the US is facing critical challenges as each unit in health industry operates independently and focuses on its own performance[31]. 


\section{Strengths and limitations}

The main strength of the CHNRI methodology can be summarized as follows: (i) clearly defined context and key criteria that qualify some actions as a funding priority over the others; (ii) transparent process for individual input and decision making in priority setting; (iii) systematic way in scoring actions, thus limiting the influence of individual biases on the outcome; (iii) prevent individuals from dominating the process; and (iv) an intuitive quantitative outcome that is easy to justify and understand.

Still, the methodology is not free of some possible biases. Although the methodology attempts to involve a wide range of opinions from the participants, many good ideas may not have been included in the initial list of actions. The listing process ended up with open-end questions that may result in multilevel answers from experts. Although efforts were made to phrase the initial actions in a better way, the process was done only by the main authors and some phrased actions may be still confusing for experts. In addition, experts understanding in "IT skills competence" and "healthcare workforce" would be a bias on the outcomes.

Another concern over the CHNRI process is that the possible bias regarding the opinions of a very limited group of experts and the results from the choice of the experts. As the study was based on EU-level, the participating experts in the study are only from 18 EU countries. The concept of "healthcare workforce" relates to a broad range of individuals with both clinical background and non-clinical background [16], however, not every expertise was involved and balanced among experts. The number of individuals who possess enough experience, expertise and knowledge on IT skills competence among healthcare workforce to evaluate the actions presented is rather limited.

Another bias could be the results from the scoring process. In order to improve the responsiveness of experts and decrease the burden of scores, a minor change was made 
to score the actions by answering one question per criteria rather than three questions according to the CHNRI guideline. It could affect the accuracy of results to some extent. As for the calculation of priority scores, the answers "yes" got 1 positive point, "no" got 0 - no extra point, if it is "undecided", a positive grade (0.5) still add to the achieved sum. Nevertheless, comparing to other priority setting methodologies mentioned above, the CHNRI approach is prominently featured in the special algorithm and limiting the individuals' bias on the outcomes.

\section{Validity}

The fundamental principle of CHNRI methodology is "wisdom of crowds", which refers to the process of taking into account the collective opinion of a group of individuals rather than a single expert to answer a question [32]. It has been shown that the average of collective guesses is often better than any expert judgment. By giving each individual the equal right and opportunity to express their own judgment, the personal biases that each one brings to the process tend to negate and diminish, regardless of the participant selection. Following the CHNRI guideline, the same action was scored by a larger group multiple times that improves the degree of accuracy.

\section{Future work}

The results from this study present a first step towards identifying the priorities of actions needed to improve the IT skills competence among healthcare workforce. Further research that includes experts with more expertise in healthcare is essential to better characterize all actions that needed for adoption of health informatics technology among workforce. One of the interesting approaches is to incorporate opinions from wider public who are interested in priority setting in health area but lack of expertise to list actions. In this way, the final priority score for each action will contain the input from both experts and the stakeholders.

The CHNRI methodology ensures transparency in scoring process, therefore, it offers 
the potential to expose the points of the greatest agreement and the greatest controversy among the experts [20]. In this case, in addition to the information on how each action fulfills with the chosen priority setting criteria, information about the amount of agreement between the experts on each action could also be obtained. Since the study context and other components of the contexts may change over time, actions can be taken so research portfolio will continuously be adjusted to the context and aim, including: (i) adding further actions to the list; (ii) adding additional criteria; (ii) rescoring all actions in the redefined context.

\section{Conclusion}

The growth of new technology, new medical appliances and diagnostic techniques is leading to new ways of healthcare delivery, which requires a new mix of skills including technical and e-skills. Improving the eHealth IT competences demands concrete actions at an international level. This exercise has led to a concerted EU effort led by a group of experts, all of whom have eHealth-related experience, identifying the priorities of actions needed to be taken for IT skills improvement. The findings are a clear call for attention to integration of eHealth in current curricula, training for both educators and healthcare workforce, raising awareness of the importance of eHealth and inclusion of workforce in the development of eHealth solutions.

This study firstly explored the actions needed to develop IT skills competence among healthcare workforce using CHNRI methodology and systematically ranked priority list for generates specific suggestions. It is definitely clear that more researches in this field are required in order to provide comprehensive understanding of actions needed to foster IT skills competence for healthcare workforce at different levels.

Acknowledgements: This work is supported by "CAMEI: Coordination Actions in the scientific era of Medical Education Informatics for fostering IT skills for healthcare workforce in the EU and USA" (http://www.camei-project.eu), a project funded under 
the Seventh Framework Programme, as a coordination and support action (ICT2013.5.1. G.A. no 611967)

Conflict of Interest Statement: The authors have no conflict of interest to declare related to the content of manuscript

\section{References}

[1] R. Suzman, J. R. Beard, T. Boerma, and S. Chatterji, "Health in an ageing world-what do we know?," Lancet, vol. 385, no. 9967, pp. 484-486, Nov. 2014.

[2] D. Yach, C. Hawkes, C. L. Gould, and K. J. Hofman, "The global burden of chronic diseases: overcoming impediments to prevention and control.," JAMA, vol. 291, no. 21, pp. 2616-22, Jun. 2004.

[3] Willy Palmand and Irene A. Glinos, "Enabling patient mobility in the EU: between free movement and coordination," in Health systems governance in Europe: the role of EU law and policy, H. T. Mossialos E, Permanand G, Baeten R, Ed. Cambridge: Cambridge University Press, 2010, pp. 509-560.

[4] D. L. Kodner and C. Spreeuwenberg, "Integrated care: meaning, logic, applications, and implications--a discussion paper.," Int. J. Integr. Care, vol. 2, p. e12, Jan. 2002.

[5] European Comission, "eHealth: a solution for European healthcare systems?," 2009.

[6] European Commission, "EU citizen report 2010: Dismantling the obstacles to EU citizens' rights. COM (2010) 603 final, 27 October 2010,” Brussels, Nov. 2010.

[7] The Chain of Trust Consortium, "Chain of Trust," 2014.

[8] S. T. Konstantinidis and P. D. Bamidis, "A Framework for a Social Semantic Registry of IT Skills for Healthcare Workforce," in 2014 IEEE 27th International Symposium on Computer-Based Medical Systems, 2014, pp. 100104. 
[9] V. Traver, S. T. Konstantinidis, P. D. Bamidis, and N. Zary, "Analysis of EUUSA cooperation opportunities on IT skills for healthcare workforce.," Stud. Health Technol. Inform., vol. 210, pp. 561-3, Jan. 2015.

[10] N. Z. Teresa Meneu, Vicente Traver, Stathis Konstantinidis, Panagiotis Bamidis, "White Paper on IT skills for healthcare workforce in the EU and USA and cooperation opportunities | CAMEI," 2014. [Online]. Available: http://www.camei-project.eu/content/live-doc-white-paper-it-skills-healthcareworkforce-eu-and-usa-and-cooperation-opportunities. [Accessed: 05-Apr2015].

[11] European Commission, "Transatlantic Cooperation Surrounding Health Related Information and Communication Technology," 2011. [Online]. Available: http://ec.europa.eu/digital-agenda/en/news/transatlanticcooperation-surrounding-health-related-information-and-communicationtechnology. [Accessed: 07-May-2015].

[12] J. Mantas, E. Ammenwerth, G. Demiris, A. Hasman, R. Haux, W. Hersh, E. Hovenga, K. C. Lun, H. Marin, F. Martin-Sanchez, and G. Wright, "Recommendations of the International Medical Informatics Association (IMIA) on Education in Biomedical and Health Informatics. First Revision.," Methods Inf. Med., vol. 49, no. 2, pp. 105-120, Jan. 2010.

[13] M. S. Fetter, "Improving information technology competencies: implications for psychiatric mental health nursing.," Issues Ment. Health Nurs., vol. 30, no. 1, pp. 3-13, Jan. 2009.

[14] S. E. Smith, L. E. Drake, J.-G. B. Harris, K. Watson, and P. G. Pohlner, "Clinical informatics: a workforce priority for 21 st century healthcare.," Aust. Health Rev., vol. 35, no. 2, pp. 130-5, May 2011.

[15] N. J. Kaufman, B. C. Castrucci, J. Pearsol, J. P. Leider, K. Sellers, I. R. Kaufman, L. M. Fehrenbach, R. Liss-Levinson, M. Lewis, P. E. Jarris, and J. B. Sprague, "Thinking beyond the silos: emerging priorities in workforce development for state and local government public health agencies," J. Public Heal. Manag. Pract., vol. 20, no. 6, pp. 557-565, Jan. 2014.

[16] WHO, "The world health report 2006: working together for health. Geneva: World Health Organization," Press, 2006.

[17] European Commission, "Transatlantic eHealth/health IT Cooperation Roadmap," 2013.

[18] I. Rudan, J. L. Gibson, S. Ameratunga, S. El Arifeen, Z. A. Bhutta, M. Black, R. E. Black, K. H. Brown, H. Campbell, I. Carneiro, K. Y. Chan, D. 
Chandramohan, M. Chopra, S. Cousens, G. L. Darmstadt, J. Meeks Gardner, S. Y. Hess, A. A. Hyder, L. Kapiriri, M. Kosek, C. F. Lanata, M. A. Lansang, J. Lawn, M. Tomlinson, A. C. Tsai, and J. Webster, "Setting priorities in global child health research investments: guidelines for implementation of CHNRI method.," Croat. Med. J., vol. 49, no. 6, pp. 720-33, Dec. 2008.

[19] J. E. Lawn, R. Bahl, S. Bergstrom, Z. A. Bhutta, G. L. Darmstadt, M. Ellis, M. English, J. J. Kurinczuk, A. C. C. Lee, M. Merialdi, M. Mohamed, D. Osrin, R. Pattinson, V. Paul, S. Ramji, O. D. Saugstad, L. Sibley, N. Singhal, S. N. Wall, D. Woods, J. Wyatt, K. Y. Chan, and I. Rudan, "Setting research priorities to reduce almost one million deaths from birth asphyxia by 2015.," PLoS Med., vol. 8, no. 1, p. e1000389, Jan. 2011.

[20] M. Tomlinson, I. Rudan, S. Saxena, L. Swartz, A. C. Tsai, and V. Patel, "Setting priorities for global mental health research.," Bull. World Health Organ., vol. 87, no. 6, pp. 438-46, Jun. 2009.

[21] L. Kapiriri, M. Tomlinson, M. Chopra, S. El Arifeen, R. E. Black, and I. Rudan, "Setting priorities in global child health research investments: addressing values of stakeholders.," Croat. Med. J., vol. 48, no. 5, pp. 618-27, Oct. 2007.

[22] EFN, "eHealth Stakeholder Group Report eSkills and Health Workforce," 2014.

[23] V. Sieber, "Diagnostic online assessment of basic IT skills in 1st-year undergraduates in the Medical Sciences Division, University of Oxford," Br. J. Educ. Technol., vol. 40, no. 2, pp. 215-226, Mar. 2009.

[24] L. L. Ornes and C. Gassert, "Computer competencies in a BSN program.," J. Nurs. Educ., vol. 46, no. 2, pp. 75-8, Feb. 2007.

[25] S. E. Smith, L. E. Drake, J.-G. B. Harris, K. Watson, and P. G. Pohlner, "Clinical informatics: a workforce priority for 21 st century healthcare.," Aust. Health Rev., vol. 35, no. 2, pp. 130-5, May 2011.

[26] M. Ehnfors and S. J. Grobe, "Nursing curriculum and continuing education: future directions.," Int. J. Med. Inform., vol. 73, no. 7-8, pp. 591-8, Aug. 2004.

[27] European Social Network, "Green Paper European Workforce for Health social work and care services," no. March, 2009.

[28] R. Fields, “The Top 10 Challenges Facing Healthcare Workers," April 05, 2011. [Online]. Available: http://www.beckershospitalreview.com/hospital- 
management-administration/the-top-10-challenges-facing-healthcareworkers.html. [Accessed: 06-Apr-2015].

[29] EUROPEAN COMMISSION, "COMMISSION STAFF WORKING DOCUMENT on an Action Plan for the EU Health Workforce," Strasbourg, 2012.

[30] P. P. George, N. Papachristou, J. M. Belisario, W. Wang, P. A. Wark, Z. Cotic, K. Rasmussen, R. Sluiter, E. Riboli-Sasco, L. Tudor Car, E. M. Musulanov, J. A. Molina, B. H. Heng, Y. Zhang, E. L. Wheeler, N. Al Shorbaji, A. Majeed, and J. Car, "Online eLearning for undergraduates in health professions: A systematic review of the impact on knowledge, skills, attitudes and satisfaction.," J. Glob. Health, vol. 4, no. 1, p. 010406, Jun. 2014.

[31] N. A. of E. (US) and I. of M. (US) C. on E. and the H. C. System, P. P. Reid, W. D. Compton, J. H. Grossman, and G. Fanjiang, "A Framework for a Systems Approach to Health Care Delivery." National Academies Press (US), 2005.

[32] J. Brand, The Crowdsourcing Handbook - Everything you need to know about Crowdsourcing. Emereo Publishing, 2012.

\section{Support Information}

S1 Table. Composition of the group of experts for listing process

S2 Table. Composition of the group of experts for scoring process

S3 Table. The final ranked list of all 23 actions with scores 


\section{Define the context and criteria}

Define the context in terms of scale (EU), target population (healthcare workforce), and target problem (deficiency of IT skills competence )

Identify the criteria:

- Likelihood of feasibility

- Likelihood of effectiveness

- Likelihood of deliverability, affordability and sustainability

- Maximum impact on competence improvement.

\section{Experts input - list and score actions}

Through the experts, list the actions and score the listed actions against the pre-determined criteria

\section{Address external stakeholders' value}

Through the lager reference group, define weights for the four criteria.

\section{Compute overall priority score}

Compute the overall priority score by the mean of scores for the four criteria.

\section{Figure 1: CHNRI methodology process}



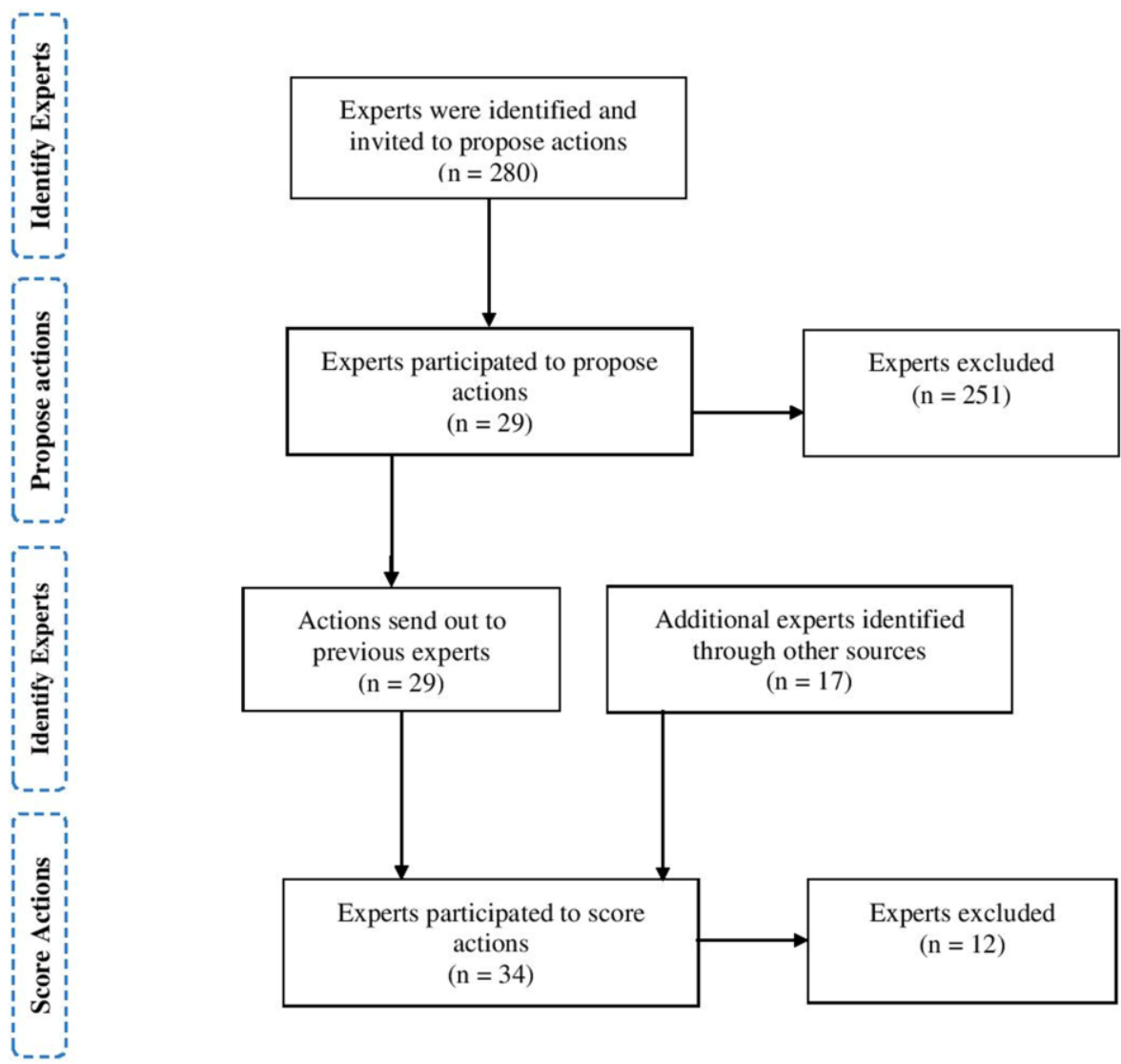

Figure 2: Experts' recruitment process 


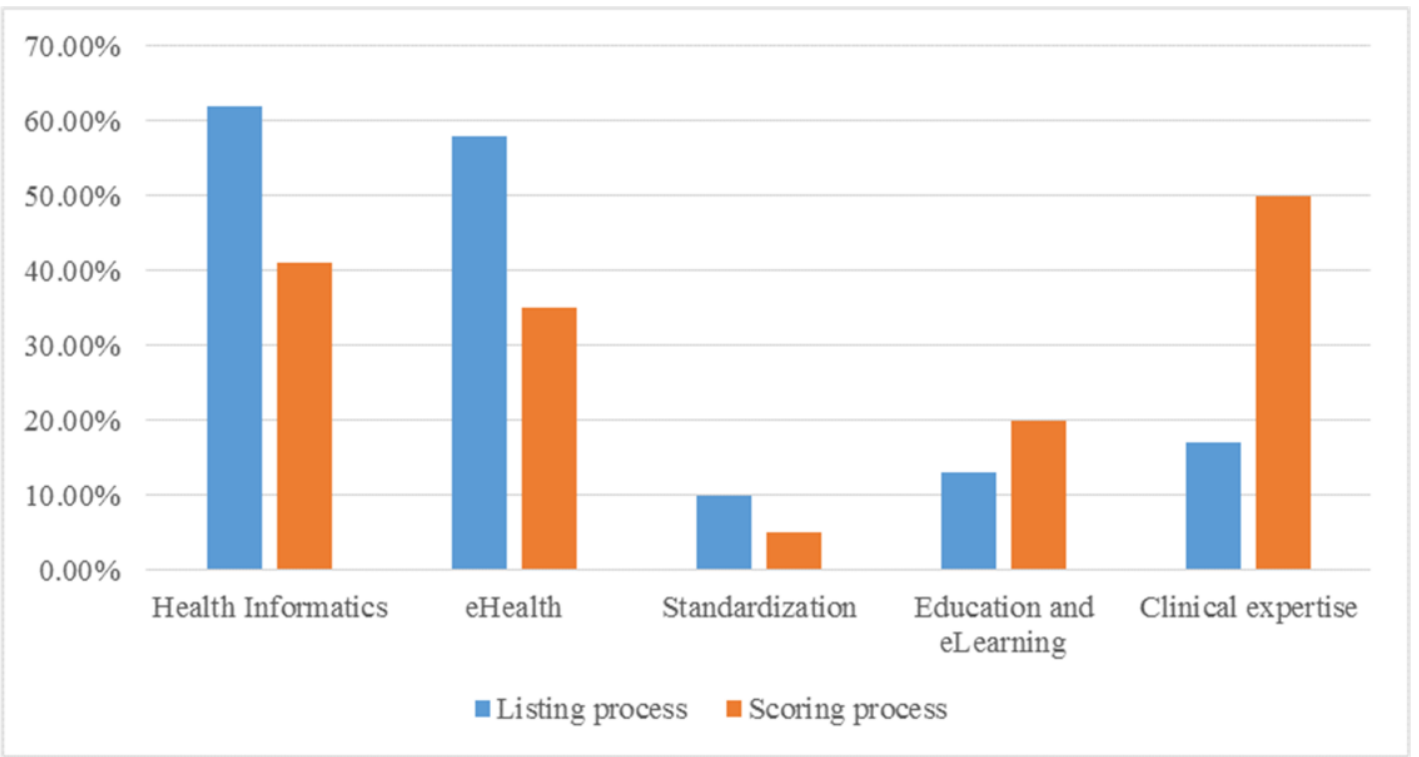

Figure 3: Experts' expertise information 
S1 Table Composition of the group of experts for listing process

\begin{tabular}{|c|c|c|c|}
\hline $\begin{array}{l}\text { Expert } \\
\text { ID }\end{array}$ & Expertise & Country & Affiliations \\
\hline 1 & $\begin{array}{l}\text { General practitioner, Clinical } \\
\text { information modelling, Health } \\
\text { informatics }\end{array}$ & UK & openEHR Foundation \\
\hline 2 & e-Learning, Education & UK & JISC \\
\hline 3 & $\begin{array}{l}\text { EHR, Hospital information } \\
\text { systems, International } \\
\text { standards }\end{array}$ & US & $\begin{array}{l}\text { HL7, AMIA, } \\
\text { Academic }\end{array}$ \\
\hline 4 & $\begin{array}{l}\text { Registered nurse (RN), Data } \\
\text { management, eLearning, Nurse } \\
\text { informatics }\end{array}$ & Finland, & IMIA, Academic \\
\hline 5 & $\begin{array}{l}\text { Medical doctor (MD), eHealth, } \\
\text { Telemedicine, Medical } \\
\text { informatics }\end{array}$ & Switzerland & AMIA, Academic \\
\hline 6 & $\begin{array}{l}\text { MD, Medical informatics, } \\
\text { Medicine }\end{array}$ & Switzerland & $\begin{array}{l}\text { HIMSS, EFMI, } \\
\text { Academic }\end{array}$ \\
\hline 7 & $\begin{array}{l}\text { Biomedical and health } \\
\text { informatics, Information } \\
\text { retrieval }\end{array}$ & US & AMIA, Academic \\
\hline 8 & Education, eLearning & UK & Academic \\
\hline 9 & Telemedicine, eHealth & Denmark & HIMSS, Academic \\
\hline 10 & $\begin{array}{l}\text { Health care management, } \\
\text { Medical informatics, eHealth, } \\
\text { Health information systems, } \\
\text { Telehealth }\end{array}$ & UK & IMIA, Academic \\
\hline 11 & $\begin{array}{l}\text { Medical software, Health } \\
\text { informatics }\end{array}$ & Germany & IMIA, Academic \\
\hline 12 & Health Informatics & Denmark & IMIA \\
\hline 13 & eHealth, Telehealth & Spain & Academic \\
\hline 14 & eHealth & Norway & Academic \\
\hline 15 & $\begin{array}{l}\text { Medical informatics, Clinical } \\
\text { decision support systems, EHR }\end{array}$ & $\begin{array}{l}\text { Czech } \\
\text { Republic }\end{array}$ & $\begin{array}{l}\text { IMIA, EFMI, } \\
\text { Academic }\end{array}$ \\
\hline 16 & Clinical information systems & Norway & IMIA, Academic \\
\hline 17 & $\begin{array}{l}\text { Health information } \\
\text { management }\end{array}$ & US & AHIMA \\
\hline 18 & Medical informatics, Health & Ireland & CBMS, Academic \\
\hline
\end{tabular}




\begin{tabular}{|l|l|l|l|}
\hline & services research & & \\
\hline 19 & $\begin{array}{l}\text { Health information systems, } \\
\text { Interoperability }\end{array}$ & Finland & HL7, IMIA, Academic \\
\hline 20 & $\begin{array}{l}\text { Clinical information systems, } \\
\text { Biomedical informatics }\end{array}$ & US & AMIA, Academic \\
\hline 21 & $\begin{array}{l}\text { Nursing Informatics, Online } \\
\text { learning, Informatics education }\end{array}$ & US & IMIA \\
\hline 22 & $\begin{array}{l}\text { Health informatics, } \\
\text { Information management }\end{array}$ & Austria & $\begin{array}{l}\text { AMIA, EFMI, } \\
\text { Academic }\end{array}$ \\
\hline 23 & $\begin{array}{l}\text { Health informatics, Health data } \\
\text { protection }\end{array}$ & Spain & IMIA \\
\hline 24 & Medical Informatics & Norway & IMIA, Academic \\
\hline 25 & $\begin{array}{l}\text { Health informatics, Clinical } \\
\text { data management }\end{array}$ & Iceland & EFMI, Academic \\
\hline 26 & $\begin{array}{l}\text { Medical and hospital IT } \\
\text { management }\end{array}$ & Belgium & HIMSS \\
\hline 28 & $\begin{array}{l}\text { Biomedical informatics, EHR, } \\
\text { Clinical decision support }\end{array}$ & $\begin{array}{l}\text { Netherlands } \\
\text { Medical Informatics, Ontology }\end{array}$ & $\begin{array}{l}\text { IMIA, EFMI, AMIA, } \\
\text { Academic }\end{array}$ \\
\hline 29 & $\begin{array}{l}\text { MD, Medical Informatics } \\
\text { Radiology }\end{array}$ & Norway & IMIA, Academic \\
\hline 27 NFMI, MIE
\end{tabular}


S2 Table Composition of the group of experts for scoring process

\begin{tabular}{|c|c|c|c|}
\hline $\begin{array}{l}\text { Expert } \\
\text { ID }\end{array}$ & Expertise & Country & Affiliations \\
\hline 1 & $\begin{array}{l}\text { Medical Education, biomedical } \\
\text { informatics }\end{array}$ & Greece & IMIA, Academic \\
\hline 2 & $\begin{array}{l}\text { Medical Informatics, Health } \\
\text { Informatics }\end{array}$ & Sweden & Academic \\
\hline 3 & MD, User Experience, eHealth & Finland & CPME, Academic \\
\hline 4 & $\begin{array}{l}\text { RN, Data management, } \\
\text { eLearning, Nurse informatics }\end{array}$ & Finland & IMIA, Academic \\
\hline 5 & eHealth & Kosovo & CPME, Academic \\
\hline 6 & $\begin{array}{l}\text { MD, Medical informatics, } \\
\text { Medicine }\end{array}$ & Switzerland & $\begin{array}{l}\text { HIMSS, EFMI, } \\
\text { Academic }\end{array}$ \\
\hline 7 & $\begin{array}{l}\text { RN, Medical science nursing, } \\
\text { Nursing education, Nursing } \\
\text { assessment }\end{array}$ & Poland & EFN, Academic \\
\hline 8 & MD, Intensive Care & Sweden & CPME \\
\hline 9 & Pharmacist & Germany & EAHP, Academic \\
\hline 10 & MD, Medication education. & Denmark & Denmark, Academic \\
\hline 11 & $\begin{array}{l}\text { Medical software, Health } \\
\text { informatics }\end{array}$ & Germany & IMIA, Academic \\
\hline 12 & Telemedicine, e-health, & Spain & ITACA, \\
\hline 13 & $\mathrm{RN}$ & Finland & EFN \\
\hline 14 & Pharmacist & Slovenia & EAHP, Academic \\
\hline 15 & Clinical Information Systems & Norway & IMIA, Academic \\
\hline 16 & $\mathrm{RN}$ & Bulgaria & EFN \\
\hline 17 & $\begin{array}{l}\text { Medical informatics, Health } \\
\text { services research }\end{array}$ & Ireland & CBMS, Academic \\
\hline 18 & $\begin{array}{l}\text { Health information systems, } \\
\text { Interoperability }\end{array}$ & Finland & HL7, IMIA, Academic \\
\hline 19 & $\begin{array}{l}\text { Clinical information systems, } \\
\text { Biomedical informatics }\end{array}$ & US & AMIA, Academic \\
\hline 20 & $\begin{array}{l}\text { Nursing Informatics, Online } \\
\text { learning, Informatics education }\end{array}$ & US & IMIA \\
\hline 21 & $\begin{array}{l}\text { Health informatics, Information } \\
\text { management }\end{array}$ & Austria & $\begin{array}{l}\text { AMIA, EFMI, } \\
\text { Academic }\end{array}$ \\
\hline 22 & $\begin{array}{l}\text { eLearning and Health } \\
\text { Informatics, computer science }\end{array}$ & Norway & Academic \\
\hline
\end{tabular}




\begin{tabular}{|l|l|l|l|}
\hline 23 & Medical Informatics & Norway & IMIA, Academic \\
\hline 24 & $\begin{array}{l}\text { Health informatics, Clinical } \\
\text { data management }\end{array}$ & Iceland & EFMI, Academic \\
\hline 25 & $\begin{array}{l}\text { Medical and hospital IT } \\
\text { management }\end{array}$ & Belgium & HIMSS Europe \\
\hline 26 & Biomedical informatics, EHR, & Netherlands & $\begin{array}{l}\text { IMIA, EFMI, AMIA, } \\
\text { Academic }\end{array}$ \\
\hline 27 & $\begin{array}{l}\text { RN } \\
\text { Clinical decision support }\end{array}$ & $\begin{array}{l}\text { Czech } \\
\text { Republic }\end{array}$ & EFN, Academic \\
\hline 29 & RN Medical Informatics & Norway & IMIA, Academic \\
\hline 30 & RN & Slovenia & EFN \\
\hline 31 & $\begin{array}{l}\text { Standard (SNOMED CT), } \\
\text { Medical Informatics, Ontology }\end{array}$ & Netherlands & EFMI, MIE \\
\hline 32 & $\begin{array}{l}\text { Primary Care and Community } \\
\text { nursing, Health Services } \\
\text { Research }\end{array}$ & UK & Academic \\
\hline 33 & Nursing, intensive care & Germany & EFN \\
\hline 34 & Education, eLearning & UK & Academic \\
\hline
\end{tabular}


$1 \quad$ S3 Table The final ranked list of all 23 actions with scores

\begin{tabular}{|c|c|c|c|c|c|c|}
\hline Rank & Actions & Feasible & Effective & Deliverable & $\begin{array}{l}\text { Maximum } \\
\text { impact }\end{array}$ & Score \\
\hline 1. & $\begin{array}{l}\text { Integrate health IT in curricula at both undergraduate } \\
\text { and postgraduate level }\end{array}$ & 92.6 & 95.5 & 75.8 & 76.7 & 85.1 \\
\hline 2. & $\begin{array}{l}\text { Inclusion of healthcare professionals in the } \\
\text { development process of the ICT-solutions }\end{array}$ & 88.2 & 92.4 & 79.0 & 78.3 & 84.5 \\
\hline 3. & $\begin{array}{l}\text { Ensure the competence for educators, train the trainer } \\
\text { in eHealth IT skills }\end{array}$ & 88.2 & 86.3 & 85.5 & 77.6 & 84.4 \\
\hline 4. & Raise awareness of the importance of eHealth & 92.6 & 89.4 & 83.9 & 70.0 & 84.0 \\
\hline 5. & $\begin{array}{l}\text { Training on patient-centered eHealth/Health IT } \\
\text { services for different professional groups }\end{array}$ & 91.2 & 89.4 & 82.2 & 71.7 & 83.6 \\
\hline 6. & $\begin{array}{l}\text { Exposure to relevant ICT solutions and medical } \\
\text { technologies, increase users' confidence in eHealth }\end{array}$ & 83.8 & 84.8 & 79.0 & 73.3 & 80.3 \\
\hline 7. & $\begin{array}{l}\text { Training on role specific and organization-specific IT } \\
\text { skills for different professional groups }\end{array}$ & 88.2 & 81.8 & 77.4 & 73.3 & 80.2 \\
\hline 8. & $\begin{array}{l}\text { Improve learning arrangements - facilities, methods, } \\
\text { equipment }\end{array}$ & 81.2 & 87.5 & 65.0 & 76.7 & 77.6 \\
\hline 9. & $\begin{array}{l}\text { Training on the development of processes and } \\
\text { activities supported by IT solutions for different } \\
\text { professional groups }\end{array}$ & 77.9 & 80.3 & 74.2 & 70.0 & 75.6 \\
\hline 10. & Increase research in user acceptance of IT for & 85.2 & 81.8 & 69.3 & 63.8 & 75.1 \\
\hline
\end{tabular}




\begin{tabular}{|c|c|c|c|c|c|c|}
\hline & healthcare workers & & & & & \\
\hline 11. & $\begin{array}{l}\text { Define IT skill training programs by regional/national } \\
\text { authorities }\end{array}$ & 79.4 & 81.8 & 65.5 & 70.0 & 74.5 \\
\hline 12. & Evaluate training program, identify barriers & 85.3 & 81.8 & 67.7 & 63.3 & 74.2 \\
\hline 13. & Investment in new technology & 77.9 & 78.8 & 75.0 & 65.0 & 74.2 \\
\hline 14. & $\begin{array}{l}\text { Introduce online training tools, e.g. MOOC, as well as } \\
\text { in housing training }\end{array}$ & 83.3 & 73.4 & 66.7 & 66.7 & 72.57 \\
\hline 15. & Help to recognize eHealth/health IT as a specialty & 81.2 & 77.2 & 67.7 & 55.0 & 70.5 \\
\hline 16. & $\begin{array}{l}\text { Identification of IT competences needed at } \\
\text { international level, allow recognition of competences } \\
\text { beyond frontiers, create of competency framework }\end{array}$ & 74.2 & 75.0 & 72.4 & 58.3 & 70.0 \\
\hline 17. & Analysis the skills needed for jobs & 77.9 & 68.1 & 71.7 & 61.7 & 69.9 \\
\hline 18. & $\begin{array}{l}\text { Carry out regular audit / evaluate of skills of existing } \\
\text { and new staff, offer qualification procedure }\end{array}$ & 82.3 & 72.7 & 53.2 & 56.7 & 66.2 \\
\hline 19. & Guarantee the governance for education and training & 73.5 & 74.2 & 53.2 & 56.7 & 64.4 \\
\hline 20. & Joint Funding for generic training programs & 66.7 & 68.2 & 55.0 & 61.7 & 62.9 \\
\hline 21. & $\begin{array}{l}\text { Set up coordinating body to support availability of } \\
\text { ICT in broad community of healthcare workers }\end{array}$ & 58.8 & 59.1 & 53.3 & 55.0 & 56.6 \\
\hline 22. & Create and use registries & 57.6 & 58.0 & 53.4 & 50.0 & 54.8 \\
\hline 23. & $\begin{array}{l}\text { Improving training on potential healthcare workforce } \\
\text { at high school level, undergraduate level }\end{array}$ & 50.0 & 51.6 & 41.4 & 48.3 & 47.8 \\
\hline
\end{tabular}

